Supporting information for:

\title{
Novel Trans-Stilbene-based Fluorophores as Probes for Spectral Discrimination of Native and Protofibrillar Transthyretin
}

\author{
Raúl I Campos ${ }^{1}$, Xiongyu Wu ${ }^{1}$, Mathias Elgland ${ }^{1}$, Peter Konradsson ${ }^{1}$, Per Hammarström ${ }^{1 *}$ \\ ${ }^{1}$ IFM - Department of Chemistry, Linköping University, Linköping, Sweden \\ *corresponding author: email: perha@ifm.liu.se, phone +4613285690
}

Contents:

1. Table $\mathrm{S} 1$

2. Figure $\mathrm{S} 1$ 
Table S1: Solvent properties

(Extracted and edited from Brady et al., Bioorg Chem. 2005 Dec;33(6):415-25.

\begin{tabular}{|c|c|c|c|}
\hline Solvent & Solvent type & Dielectric constant $\varepsilon$ & $\begin{array}{c}\text { Viscosity } \eta(\mathrm{mPa} s) \\
\left(20^{\circ} \mathrm{C}\right)\end{array}$ \\
\hline PBS (water) & Polar protic & 80.1 & 1 \\
\hline Ethylene glycol & Polar protic & 37.7 & 13.5 \\
\hline Glycerol & Polar protic & 42.5 & 945 \\
\hline Ethanol & Polar protic & 25 & 1.2 \\
\hline Methanol & Polar protic & 33.6 & 0.59 \\
\hline Dimethylsulfoxide & Dipolar aprotic & 48.9 & 2.47 \\
\hline Dimethylformamide & Dipolar aprotic & 38.3 & 0.85 \\
\hline Acetone & Dipolar aprotic & 20.7 & 0.32 \\
\hline Methylene chloride & Non-polar & 9.14 & 0.44 \\
\hline Toluene & Non-polar & 2.39 & 0.59 \\
\hline
\end{tabular}


A

Native TTR + SB 11

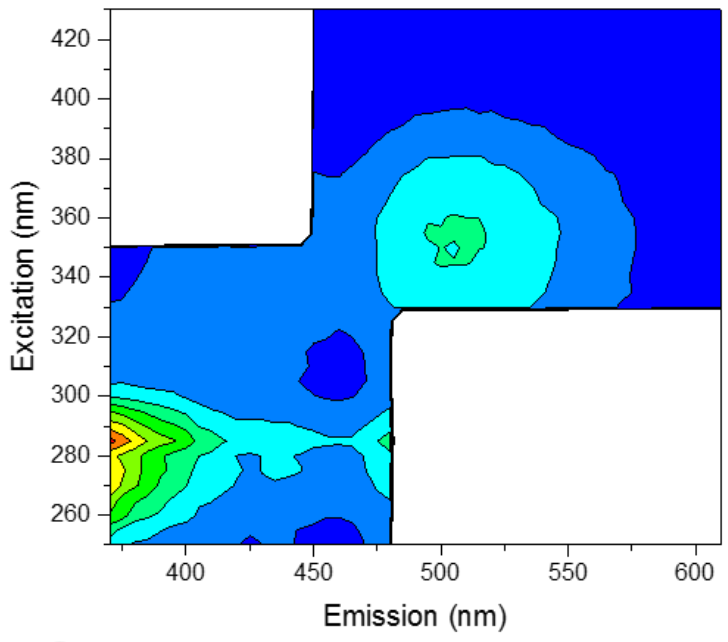

C

Free SB 11 (Native TTR buffer)

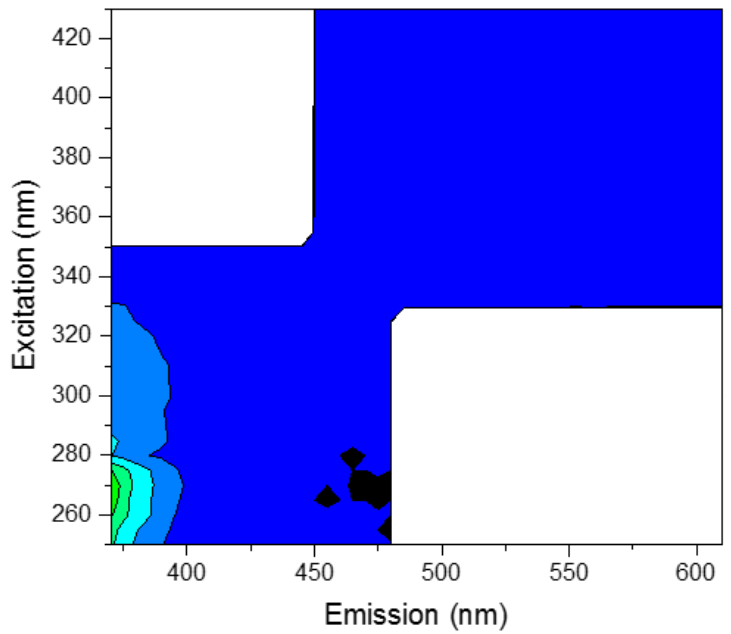

B

TTR protofibrils + SB 11

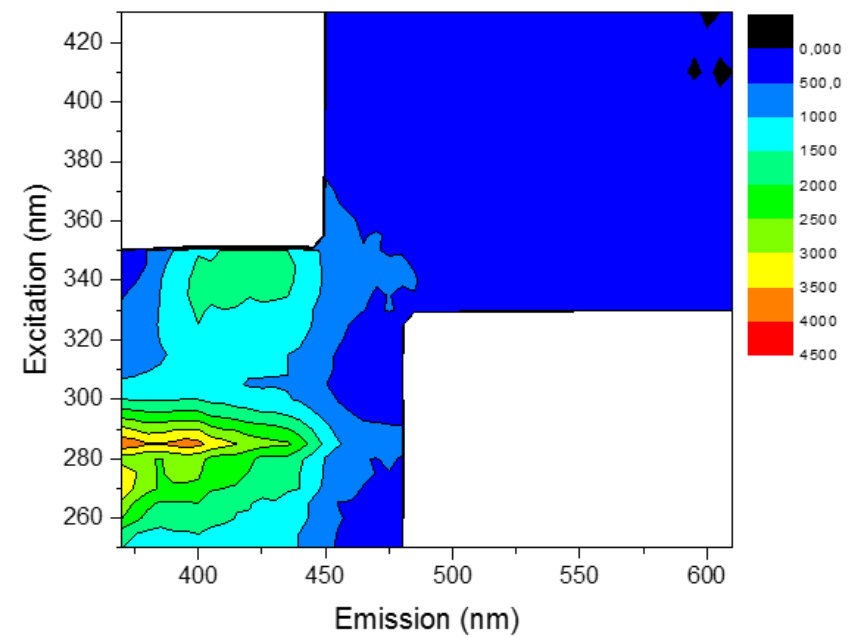

D

Free SB 11 (protofibrils buffer)

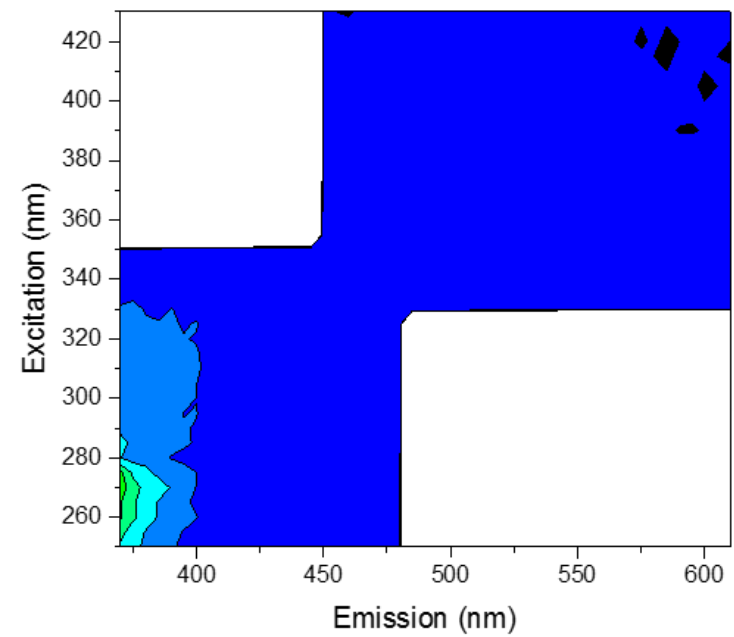

Figure S1: Fluorescence excitation-emission plots of SB 11 bound to native TTR and TTR protofibrils. SB 11 $(1.8 \mu \mathrm{M})$ was added to native TTR $(A)$ or TTR protofibrils $(B)(0.1 \mathrm{mg} / \mathrm{mL})$ and 2D spectra in each case were acquired and combined in 3D-heat maps representing intensity as a color code from low (blue) to high intensity (red). C) and D) show the 2D combined spectrum of SB 11 in each respective buffer as control. 